\title{
Growth and total-N content of Prosopis juliflora (SW) D. C. are stimulated by low $\mathrm{NaCl}$ levels
}

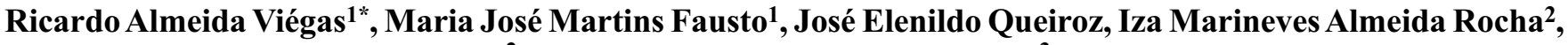 \\ Joaquim Albenísio Gomes Silveira ${ }^{2}$ and Pedro Roberto Almeida Viégas ${ }^{3}$
}

\begin{abstract}
${ }^{1}$ Laboratório de Nutrição Florestal e Estresse de Plantas, Departamento de Engenharia Florestal da UFPB, Campus VII, CP 64, CEP 58700-970, Patos, Paraiba, Brasil; ${ }^{2}$ Laboratório de Metabolismo e Estresse de Plantas, Departamento de Bioquímica e Biologia Molecular, Universidade Federal do Ceará, CP 6020, CEP 60451-970, Fortaleza, Ceará, Brasil; ${ }^{3}$ Laboratório de Nutrição Mineral de Plantas, Departamento de Agronomia, CEP 55100-000, Aracaju, Sergipe, Brasil.*Corresponding author: raviegas@uol.com.br
\end{abstract}

Received: 10/10/2003, Accepted: 09/02/2004

In this study the early effects of salinity on growth, total $\mathrm{N}$ and ion accumulation and partitioning in Prosopis juliflora (common name algaroba) were studied with 30-day-old plants grown for 8 days in aerated nutrient solution (NS) free of (control) or supplied with 25, 50, 75 and 100 mmol.L $\mathrm{L}^{-1} \mathrm{NaCl}$. Plants grown in 25 and $50 \mathrm{mmol} . \mathrm{L}^{-1} \mathrm{NaCl}$ accumulated a total dry mass (DM) and shoot $\mathrm{N}$ content greater than the control. However, at 75 and $100 \mathrm{mmol} . \mathrm{L}^{-1} \mathrm{NaCl}$ such parameters were diminished. Whole plant transpiration rates were higher with 25 and $50 \mathrm{mmol} . \mathrm{L}^{-1} \mathrm{NaCl}$ and lower with 75 and $100 \mathrm{mmol} \cdot \mathrm{L}^{-1} \mathrm{NaCl}$. Salinity did not influence shoot $(80 \%)$ and root $(70 \%)$ water content (WC) but reduced the $\mathrm{K}^{+}$content of shoot while that of root was not affected. Increasing external $\mathrm{NaCl}$ concentrations increased $\mathrm{K}^{+} / \mathrm{Na}^{+}$ratios of both plant parts. The data support the hypothesis that increase in transpiration rates and in shoot total $\mathrm{N}$ may account for growth stimulation of algaroba under mild salinity.

Keywords: ion partitioning, nitrogen, salinity stress.

Crescimento e teor de N-total em Prosopis juliflora (SW) D.C. são estimulados em baixos níveis de NaCl: Os efeitos iniciais da salinidade sobre o crescimento, o conteúdo total de $\mathrm{N}$ e o acúmulo e a distribuição de íons foram investigados em plantas de algarobeira (Prosopis juliflora (SW) D.C.) com 30 dias de idade cultivadas em solução nutritiva sem controle ou com 25, 50, 75 e 100 mmol.L-1 de NaCl, durante 8 dias. Em 25 e 50 mmol.L $\mathrm{L}^{-1} \mathrm{de} \mathrm{NaCl}$, as plantas exibiram maior acumulação de massa seca (MS) e conteúdo de $\mathrm{N}$ total na parte aérea que as plantas controle. Contrariamente, esses parâmetros foram reduzidos nas plantas cultivadas em 75 e 100 mmol.L ${ }^{-1}$ de NaCl. As taxas de transpiração das plantas cultivadas em 25 e 50 mmol. $\mathrm{L}^{-1} \mathrm{de} \mathrm{NaCl}$ foram aumentadas enquanto, em 75 e 100 mmol. $\mathrm{L}^{-1} \mathrm{de} \mathrm{NaCl}$, foram reduzidas, comparadas ao controle. $\mathrm{O}$ conteúdo de água da parte aérea $(80 \%)$ e das raízes $(70 \%)$ não foi afetado pela salinidade, enquanto que os teores de $\mathrm{K}^{+}$da parte aérea foram reduzidos, mas não alterados nas raízes. $\mathrm{O}$ aumento da salinidade provocou reduções na relação $\mathrm{K}^{+} / \mathrm{Na}^{+}$na parte aérea e nas raízes. É sugerido que aumentos no conteúdo de $\mathrm{N}$ total e nas taxas de transpiração podem ter provocado estímulo no crescimento das plantas de algarobeira em baixa salinidade.

Palavras-chave: estresse salino, nitrogênio, partição de íons.

Salt tolerance has been partially linked to the regulation of shoot $\mathrm{Cl}^{-}$and $\mathrm{Na}^{+}$concentration (Teleisnik and Grunberg, 1994), and it has been suggested that growth under salinity stress is the result of processes such as ion transport and compartmentation and synthesis and accumulation of osmotic solutes (Viégas et al., 2001). These processes lead to osmotic adjustment and particularly exclusion and/or compartmentation of specific ions such as $\mathrm{Na}^{+}$at a level compatible to plant growth (Munns and Termaat, 1986; Delauney and Verma, 1990; Silveira et al., 2003). $\mathrm{NaCl}$ stress has been related to increased contents of $\mathrm{Na}^{+}$and $\mathrm{Cl}^{-}$and to a decreased availability of nutrients arising from a lower uptake and the competition between nutrients such as $\mathrm{K}^{+}$and $\mathrm{NO}_{3}^{-}$ with $\mathrm{Na}^{+}$and $\mathrm{Cl}^{-}$, respectively (Bottacin et al., 1984). In 
addition, salinity has been reported to disturb the integrity of cell membranes by inducing changes in its structure (Kuiper, 1984). With respect to the plasma membrane, $\mathrm{Na}^{+}$can displace $\mathrm{Ca}^{2+}$ which constitutes a primary response to salinity stress (Cramer et al., 1985), and $\mathrm{K}^{+} / \mathrm{Na}^{+}$selectivity may be altered. According to Niu et al. (1995), increased $\mathrm{K}^{+} / \mathrm{Na}^{+}$selectivity of the $\mathrm{K}^{+}$uptake system might represent a significant adaptation to high concentrations of $\mathrm{NaCl}$.

The present study aimed to identify the relative extent to which $\mathrm{K}^{+}$and total $\mathrm{N}$ contents are affected by salinity together with the pattern of $\mathrm{Na}^{+}$accumulation and partitioning between shoot and roots as well as that of whole plant transpiration rates of algaroba (Prosopis juliflora (SW) D.C.). This was carried out by placing algaroba seedlings (when shoot was 6 to $7 \mathrm{~cm}$ in height) in $2.2 \mathrm{~L}$ vessels containing half strength Hoagland and Arnon nutrient solution (NS). The $\mathrm{pH}$ of nutrient solution was kept at $5.5 \pm 0.5$. Salinity stress was imposed by transferring 30-day-old plants grown to full strength NS containing 25, 50, 75 and 100 mmol.L $\mathrm{L}^{-1} \mathrm{NaCl}$. The effects of $\mathrm{NaCl}$ on the growth and metabolic parameters were verified $8 \mathrm{~d}$ later. Plants grown in $\mathrm{NS}$ free of $\mathrm{NaCl}$ were taken as control. At harvest, the roots were thoroughly washed in distilled water, detached from the shoot and DM determined after drying at $90^{\circ} \mathrm{C}$ to constant mass. Dried plant tissue was ground to a fine powder and subjected to wet digestion with $\mathrm{HNO}_{3}: \mathrm{HClO}_{4}(4: 1, \mathrm{v} / \mathrm{v})$ (Chapman and Pratt, 1961); the resulting solutions were diluted as necessary and analyzed for $\mathrm{K}^{+}$and $\mathrm{Na}^{+}$content by flame photometry. The total $\mathrm{N}$ content was determined by the microkjeldahl method as described by Viégas et al. (2001).

Estimates of whole plant transpiration rates were carried out at $0,2,4,6$ and $8 \mathrm{~d}$ after starting $\mathrm{NaCl}$ treatments through reduction of the volume of the nutrient solution in each pot (Reed and Hagerman, 1980); comparable pots with nutrient solution but without plants were used to correct for nontranspirational evaporation. Root and shoot water contents were determined by weighing tissue before (fresh mass - FM) and after complete drying (dry mass - DM) using an analytical balance (Silveira et al., 2003). The experiment was carried out in a greenhouse (temperature of $38 / 25^{\circ} \mathrm{C}$ day/night; relative humidity of $30 / 45 \%$ day/night). The maximal photon flux density at the plant canopy was about $2,200 \mu \mathrm{mol} \cdot \mathrm{m}^{-2} \cdot \mathrm{s}^{-1}$. The experiment consisted of 5 independent replicates per treatment, each comprised of 1 plant. Statistical analysis of the results was carried out with the STATGRAPHICS package for calculation of the standard error (SE). ANOVA was calculated with the SIGSTAT package.
Total DM of plants grown in 25 and $50 \mathrm{mmol} . \mathrm{L}^{-1} \mathrm{NaCl}$ was about $17 \%$ and $22 \%$ greater than the control, respectively (figure 1A). This is evidence that the photosynthetic apparatus of algaroba was able to provide the carbon for growth stimulation. In addition, DM accumulation of $\mathrm{NaCl}$ treated plants was low in the root compared with the shoot (figure 1B); furthermore shoot/root ratios increased by increasing external $\mathrm{NaCl}$ (figure $1 \mathrm{C}$ ). This may partly be due to a change in the pattern of export of carbohydrates and/or N-compounds from shoot to the root (Silveira et al., 2003).
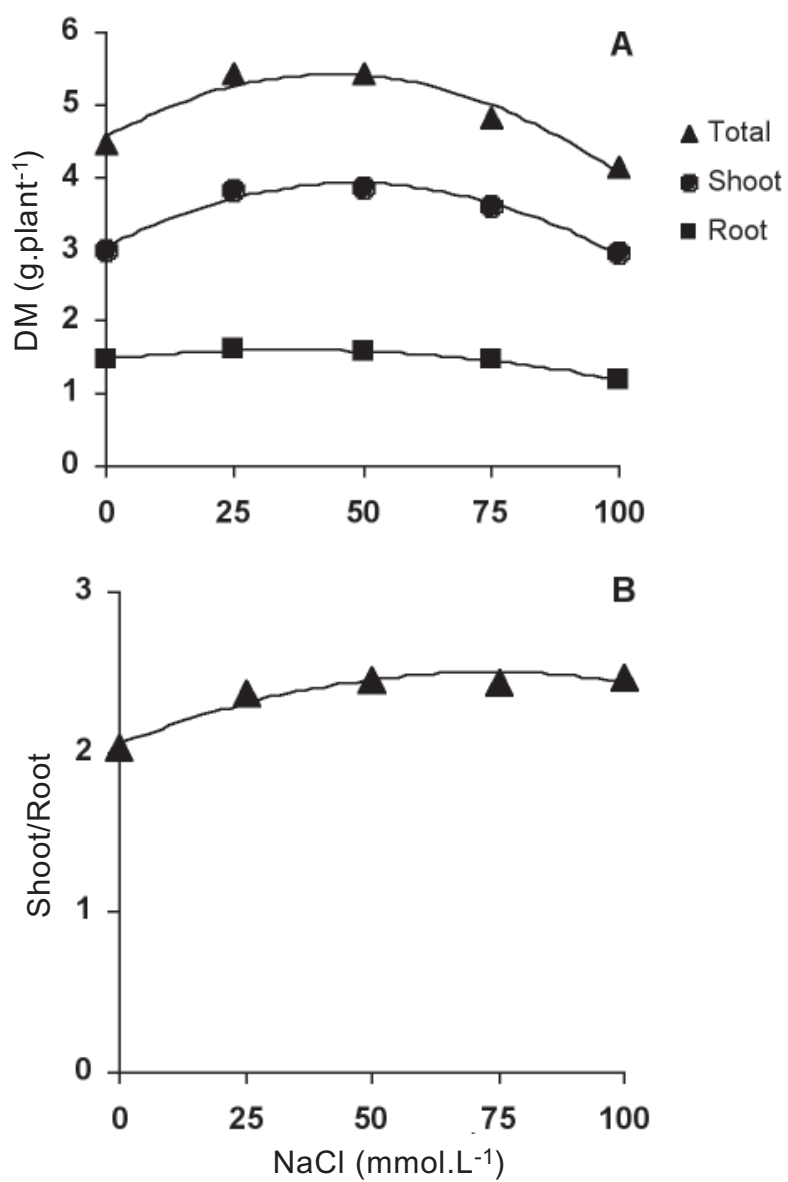

Figure 1. Shoot, root and total plant dry mass (A), and shoot/ root ratio (B) of algaroba seedlings grown hydroponically under different levels of $\mathrm{NaCl}$, during $8 \mathrm{~d}$ (short-term experiment). DM: dry mass.

On the $2^{\text {nd }}$ day of experiment, the whole plant transpiration rates of $\mathrm{NaCl}$ treated plants dropped abruptly (figure 2A). Since water transport is a passive process (Viégas et al., 2001) the abnormal increase of external $\mathrm{NaCl}$ may have created an unfavorable $\Delta \psi$ across the root cell membrane making it difficult for the plant to keep water absorption comparable to the control. On the $4^{\text {th }}$ day, the whole transpiration rates of plants grown in 25 and 50 mmol. $\mathrm{L}^{-1}$ 
$\mathrm{NaCl}$ started to increase and became higher than control plants by the end of the $\mathrm{NaCl}$ exposure time. This points toward osmotic adjustment by possible vacuolar compartmentation of inorganic ions and/or compatible solutes. Yet, despite reduced transpiration rates of plants grown in 75 and 100 mmol. $L^{-1} \mathrm{NaCl}$ (figure 2A) the plants never became subjected to water stress; in both cases, the $\mathrm{WC}$ of shoot $(80 \%)$ and root $(70 \%)$ did not differ from those of the respective controls (figure 2B).

The shoot $\mathrm{K}^{+}$content of plants grown in $100 \mathrm{mmol. \textrm {L } ^ { - 1 }}$ $\mathrm{NaCl}$ represented about $30 \%$ that of control and $\mathrm{DM}$ accumulation decreased substantially. Conversely, plants grown in $50 \mathrm{mmol} . \mathrm{L}^{-1} \mathrm{NaCl}$ had a total $\mathrm{DM}$ higher than the control regardless of shoot $\mathrm{K}^{+}$being 1.7-fold lower (figures
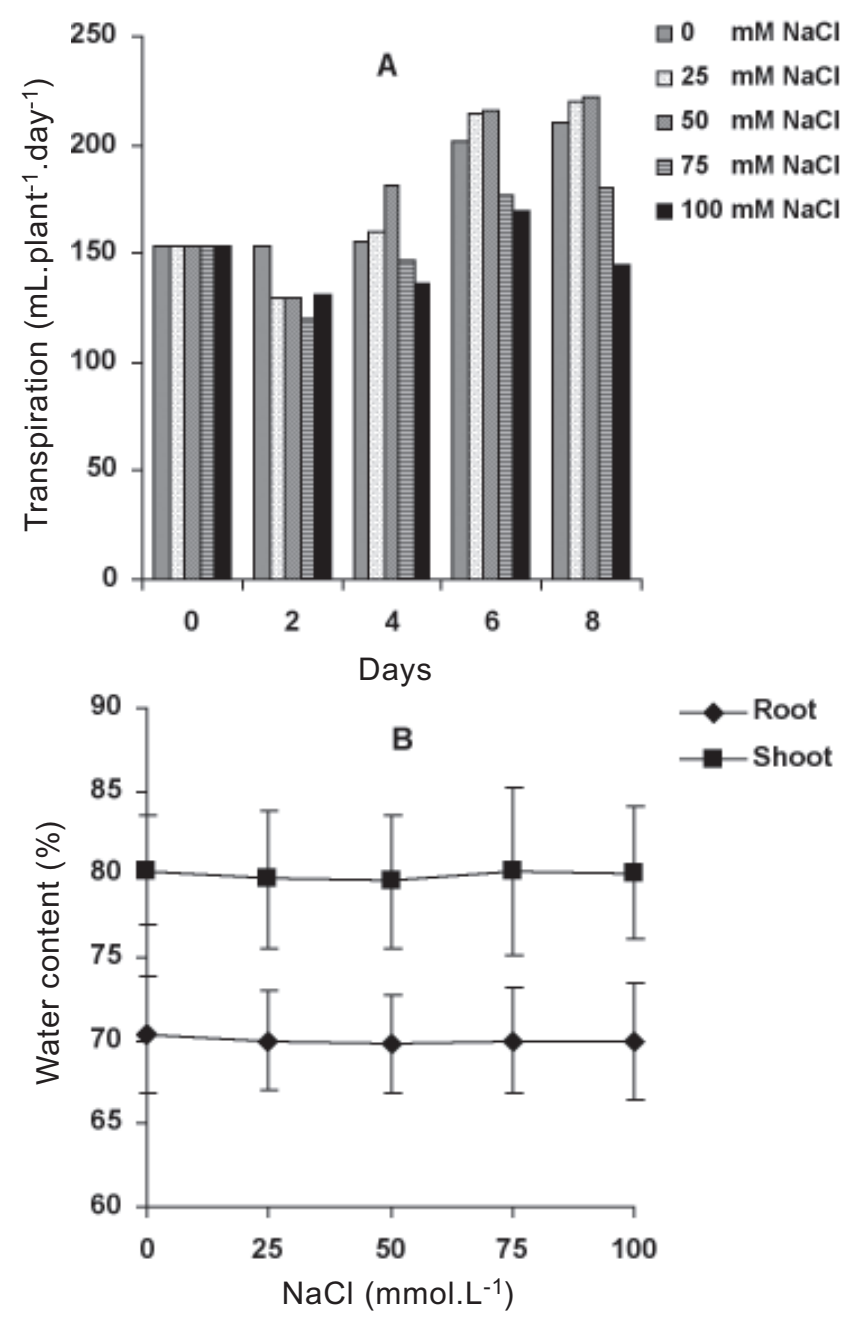

Figure 2. Whole plant transpiration rates (A) and tissue water content (B) of algaroba seedlings grown hydroponically under different levels of $\mathrm{NaCl}$, during $8 \mathrm{~d}$ (short-term experiment). ANOVA results of (A): $\mathrm{NaCl}^{* *}(\mathrm{~S}), \mathrm{Time}^{* *}$ $(\mathrm{T})$ and $(\mathrm{S} \times \mathrm{T})^{* *} .{ }^{* *}$ : Significant at $\mathrm{P}=0.01$ (F test). Vertical bars represent \pm SE for $n=5$.
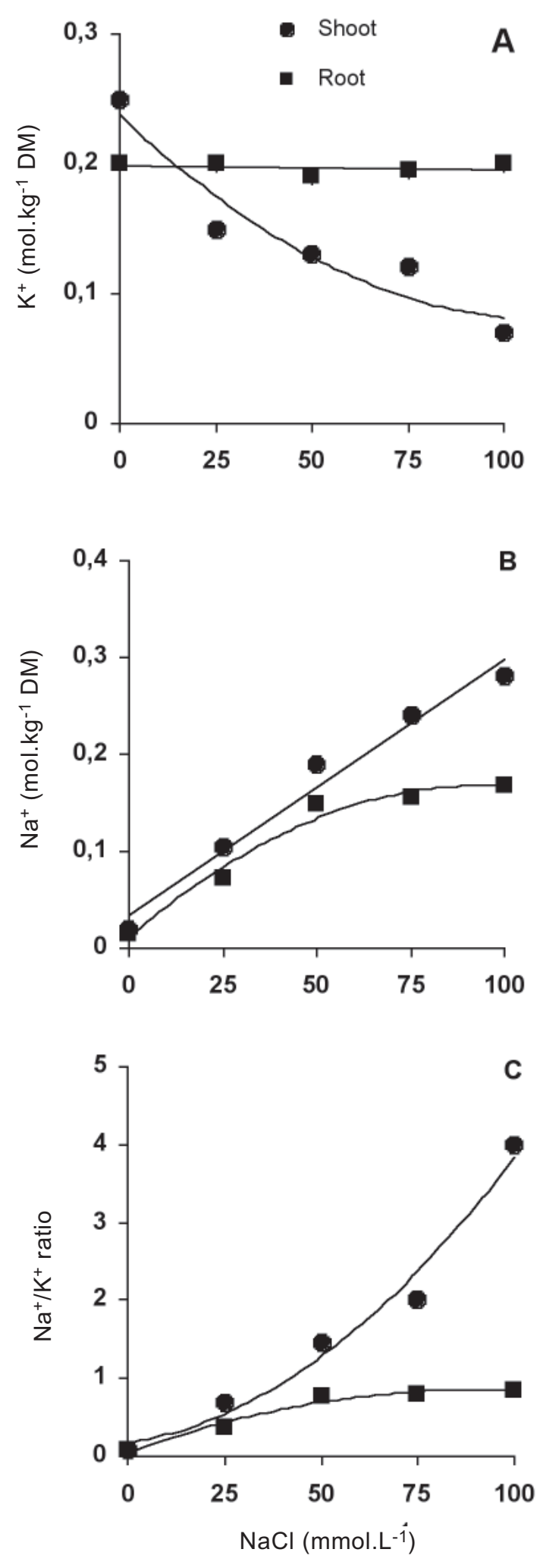

Figure 3. Accumulation of $\mathrm{K}^{+}(\mathrm{A})$ and $\mathrm{Na}^{+}(\mathrm{B})$ in shoot and root and $\mathrm{K}^{+} / \mathrm{Na}^{+}$ratios $(C)$ of algaroba seedlings grown hydroponically under different levels of $\mathrm{NaCl}$, during eight days (short-term experiment). DM: dry mass. 
$1 \mathrm{~A}$ and $3 \mathrm{~A}$ ). Since a decline of shoot $\mathrm{K}^{+}$is taken to indicate that salinity is limiting growth (Erdei and Teleisnik, 1993), the present results suggest this to be limited to a particular condition; therefore, such interpretation depends on the plant species and $\mathrm{NaCl}$ level. The accumulation of root $\mathrm{Na}^{+}$ approached a plateau under $50 \mathrm{mmol} . \mathrm{L}^{-1} \mathrm{NaCl}$ while in the shoot it increased linearly at all salt concentrations (figure 3B). These results show $50 \mathrm{mmol} \cdot \mathrm{L}^{-1}$ to be a threshold concentration of $\mathrm{NaCl}$ in which algaroba plants were not able to avoid excess accumulation of $\mathrm{Na}^{+}$in the shoot. Furthermore, the fact that $\mathrm{Na}^{+}$of the shoot and root greatly increased while $\mathrm{K}^{+}$decreased in the former and did not change in the latter resulted in increased $\mathrm{Na}^{+} / \mathrm{K}^{+}$ratio, particularly in the shoot (figure 3C), this may be due to a reduction of $\mathrm{K}^{+} /$ $\mathrm{Na}^{+}$selectivity (Viégas et al., 2001) and/or competition between $\mathrm{Na}^{+}$and $\mathrm{K}^{+}$during uptake. The fact that root $\mathrm{K}^{+}$of $\mathrm{NaCl}$ treated plants did not change might imply that $\mathrm{NaCl}$ does not affect root membrane permeability. Consequently reduction of $\mathrm{K}^{+}$in the shoot is thought to be the result of increasing $\mathrm{K}^{+}$efflux to the bathing solution and/or decreasing $\mathrm{K}^{+}$translocation from root to shoot (Schroeder et al., 1994; Maathius et al., 1996).

The total $\mathrm{N}$ content in shoot of algaroba increased by about $18 \%$ from 0 to 50 mmol. $\mathrm{L}^{-1} \mathrm{NaCl}$ and then decreased to a level comparable to the control above $50 \mathrm{mmol} . \mathrm{L}^{-1} \mathrm{NaCl}$ (figure 4). This shows that low external $\mathrm{NaCl}$ concentrations induce $\mathrm{N}$ compound fractions to increase although the underlying mechanism has not been identified. Nevertheless, there was a strongly relationship between total $\mathrm{N}$ content of shoot $\left(\mathrm{r}^{2}=0.96\right)$ and total DM gain $\left(\mathrm{r}^{2}=0.97\right)$ with whole plant transpiration rates, showing that the metabolic process of $\mathrm{N}$ and $\mathrm{C}$ reduction is at least dependent upon plant water flux.

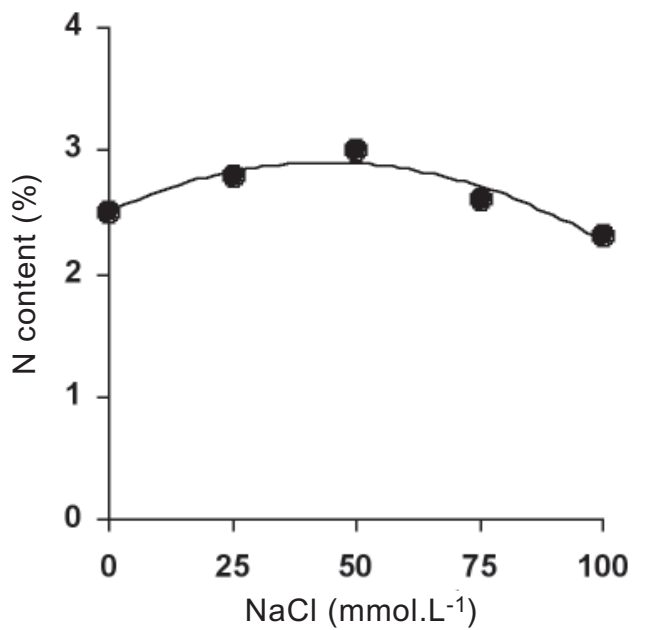

Figure 4. Total $\mathrm{N}$ content in shoot of algaroba seedlings grown hydroponically under different levels of $\mathrm{NaCl}$, during eight days (short-term experiment). DM: dry mass.
In conclusion, understanding the mechanisms that cause shoot $\mathrm{N}$ content of algaroba to increase could help establish biochemical targets for breading programs aimed at increasing salinity resistance of plants. Furthermore, Prosopis juliflora seems to have an efficient mechanism of osmotic adjustment that functions by possible vacuolar compartmentation of $\mathrm{Na}^{+}$ and/or $\mathrm{N}$ fractions allowing plants to maintain their metabolic functions compatible with growth stimulation under conditions of mild salinity. In addition, tissue water content was not a limiting factor for growth of Prosopis juliflora plants in an induced short-term salinity.

\section{REFERENCES}

Bottacin A, Cacco G, Saccomani M (1984) Nitrogen absorption and assimilation in NaCl-resistant and $\mathrm{NaCl}-$ susceptible millet genotypes (Pennisetum americanum). Can. J. Bot. 63:517-520.

Cramer GR, Lauchli A, Polito VP (1985) Displacement of $\mathrm{Ca}^{+}$by $\mathrm{Na}^{+}$from the plasmalemma of root cells. Plant Physiol. 79:207-211.

Delauney AJ, Verma DPS (1990) A soybean gene encoding 1-pyrroline-5-carboxylate reductase was isolated by functional complementation in Escherichia coli and is found to be osmoregulated. Physiol. Plant. 221:299-305.

Erdei L, Teleisnik F (1993) Changes in water relation parameters under osmotic and salt stresses in maize and sorghum. Physiol. Plant. 89: 381-387.

Kuiper PJC (1984) Functioning of plant cell membranes under saline conditions. Membrane lipid composition and ATPases. In: R. C. Staples and Toenniessen (eds), Salinity tolerance in plants, pp.77-91. New York.

Maathuis FJM, Dawn VF, Smith FA, Sanders D, Fernández JA, Walker NA (1996) The physiological relevance of $\mathrm{Na}^{+}-$ coupled $\mathrm{K}^{+}$-transport. Plant Physiology 112:1609-1616.

Munns R, Termaat A (1986) Whole plant responses to salinity. Aust. J. Plant Physiol. 13:143-160.

Niu X, Bressan RA, Hasegawa PM, Pardo JM (1995) Ion homeostasis in $\mathrm{NaCl}$ stress environments. Plant Physiol. 109:735-742.

Reed AJ, Hageman RH (1980) Relationship between nitrate uptake, flux, and reduction and the accumulation of reduced nitrogen in maize (Zea mays L.). Plant Physiol. 66:1179-1183.

Schroeder JI, Ward JM, Gassmann W (1994) Perspectives on the physiology and structure of inward-rectifying $\mathrm{K}+$ channels in higher plants: biophysical implications for $\mathrm{K}^{+}$ uptake. Ann. Rev. Biophys. Biomol. Struct. 23:441-471.

Silveira JA, Viégas RA, Rocha IMA, Monteiro ACO, Moreira RA, Oliveira JTA (2003) Salt induced effects on proline accumulation is related to proteolysis and GS activity. J. Plant Physiol. 160:115-123.

Teleisnik E, Grunberg K (1994) Ion balance in tomato cultivars differing in salt tolerance. Physiol. Plant. 92:528-534.

Viégas, RA, Silveira, JAG, Junior, ARL, Queiroz, JE, Fausto, MJM (2001) Effects of $\mathrm{NaCl}$ salinity on growth and inorganic solute accumulation in young cashew plants. Brazilian J. Agric. Environ. Engin. 5:. 216-222. 